\title{
MICROSPORIDIOSIS IN A BRAZILIAN UNIVERSITY HOSPITAL. CASE REPORT
}

\section{SUMMARY}

This is the report on a patient with chronic diarrhea caused by microsporidia. He is married, infected with HIV and has low CD4 cell count. The diagnosis was established through stool parasite search using concentration methods and Gram - chromotrope staining technique. Ileum biopsy was also performed in this case. The etiological diagnosis may be established in a clinical laboratory, by chromotrope staining technique in routine microscopic examination of stool specimens.

KEYWORDS: Diagnosis; Parasitology; Microsporidia; Chronic diarrhea; HIV.

\section{INTRODUCTION}

Microsporidia are obligate spore forming intracellular parasites that belong to the phylum Microspora. They infect a wide range of invertebrate and vertebrate hosts. Over 100 genera and 1,000 species have been described but as many as 15 species are associated with human disease. This is transmitted through the fecal-oral route and the mature Microsporidia spores are gram-positive $e^{9,10,11}$. Microsporidia are usually frequent in HIV patients with CD4 lymphocyte counts of less than 50 cells per $\mathrm{mm}^{3}$. They are generally identified in immunodeficient patients but have also been found in immunocompetent patients ${ }^{9,10}$. Most species responsible for human microsporidiosis are identified as Enterocytozoon bieneusi that infect enterocytes, and are associated with chronic diarrhea, fever, nausea, general malaise and weight $\operatorname{loss}^{9,10}$. Encephalitozoon intestinalis, another species of microsporidia, also infects enterocytes, macrophage and endothelial cells resulting in a general infection ${ }^{9,10}$. Other microsporidia species are associated with focal or disseminated infections ${ }^{8,9,10}$. The laboratory diagnosis is based on the demonstration of microsporidia spores in clinical specimens. A wide range of techniques such as chromotrope - based staining techniques, electron microscopy, serologic and molecular techniques are available for the identification of microsporidia spores ${ }^{6,7,8,9}$. The purpose of this report is to identify emerging intestinal parasitic infections in chronic diarrhea, such as microsporidia, using the Gram - chromotrope staining technique ${ }^{10}$ in routine clinical laboratory instead of invasive procedures through histopathology of biopsy specimens.

\section{CASE REPORT}

LNS, 34 year-old male, born in Cruz das Almas, BA, living in São Paulo, SP, married and HIV positive. He was sent to the "Hospital das Clínicas" of the University of São Paulo Medical School, because of progressive respiratory distress in the last two weeks, chronic diarrhea, and loss of conscience due to dehydration and electrolyte imbalance. The CD4+ T cell count was 7 cells/ $\mu \mathrm{L}$, and the viral load was 200,000 copies of viral RNA/mL plasma. Ileum biopsy showed cytomegalovirus infection, treated successfully with biovir and efavirenz, twice a day for six days, while the CD4+ T cell count was 90 cells/ $\mu \mathrm{L}$. He was discharged from the hospital and returned one year later with chronic diarrhea and weight loss. Eight parasite analyses in stool specimens were performed by sedimentation and flotation concentration, all with negative results. Ileum biopsy was performed with detection of microsporidia. Treatment with $400 \mathrm{mg}$ albendazole (one vial every two days for six weeks) showed no improvement. The CD4+ T cell count was 65 cells/ $\mu \mathrm{L}$. A month later, stool specimens were processed by concentration methods for the identification of helminths and protozoa and Gram - chromotrope stained. The parasite was detected by light microscopy in Gram - chromotrope stained ${ }^{10}$ stool samples. Spores of 1 to $1.5 \mu \mathrm{m}$, stained in violet to wine, with a distinctive diagonal or equatorial line which represents the polar tube (Fig. 1) were found. The patient was treated successfully with $400 \mathrm{mg}$ albendazole, associated with $1 \mathrm{~g}$ ciprofloxacin and vancomycin, twice a day for six days, being discharged from the hospital. The CD4+ T cell count was 123 cells $/ \mu \mathrm{L}$.

\section{DISCUSSION}

Most described cases of human microsporidiosis were in patients with AIDS and characterized by chronic diarrhea. The epidemiology is poorly understood, but this infection is probably transmitted by fecaloral route and the possible sources of infections are animals and infected persons, suggesting that microsporidia is a zoonotic parasite ${ }^{7,9}$. Recognition of human microsporidiosis as caused by opportunistic pathogens in HIV patients has increased; however, it has been also 


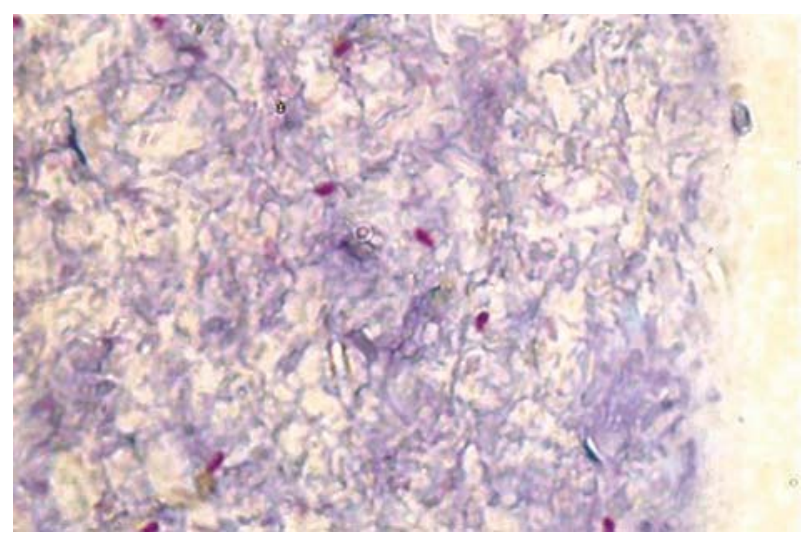

Fig. 1 - Spores of microsporidia in stool specimen stained by the Gram-chromotrope technique. Magnification: $1400 \mathrm{X}$.

identified in patients without immunosuppression. In Brazil cases have been reported, mainly in São Paulo ${ }^{1}$, Rio de Janeiro ${ }^{2,3,4,5,10}$ and Fortaleza ${ }^{11}$.

Human microsporidiosis is probably underdiagnosed because it is not detected in routine parasitological examinations. The laboratory diagnosis is based on techniques such as chromotrope - based staining techniques, electron microscopy, serologic and molecular techniques for the identification of microsporidia spores in tissues and fluids ${ }^{8,9}$.

This paper describes a case of human microsporidiosis in a patient with AIDS, where no other pathogens that could cause diarrhea were found. This case responded to treatment with albendazole.

The microsporidia spores were detected using Gram - chromotrope $\operatorname{stain}^{10}$, which is simple using only a light microscope. It was sufficient to establish the diagnosis, reducing the need for invasive procedures.

This case showed that human microsporidiosis might be a much more common emerging parasitosis causing chronic diarrhea than has been considered by the clinicians. The laboratory should routinely include methods for the diagnosis of microsporidia spores in stool samples in all patients with chronic diarrhea.

Early identification of Microsporidia would allow the prompt administration of specific treatment.

\section{RESUMO}

\section{Microsporidíase em Hospital Universitário no Brasil. Relato de caso}

Este é o relato de caso de doente com diarréia crônica causada por Microsporidia. O doente era homem, casado, infectado com HIV e tinha baixa taxa de linfócitos $\mathrm{CD} 4+$. O diagnóstico foi feito em exame de fezes utilizando métodos de concentração e técnica de coloração de Gram-Chromotrope. Biópsia de íleo também foi realizada neste caso. O diagnóstico etiológico pode ser feito em laboratório clínico, por técnicas de coloração baseada em cromotrope na rotina da observação microscópica direta.

\section{ACKNOWLEDGEMENTS}

Parasitology Service of the Central Laboratory Division (LIM 03) at the "Hospital das Clínicas" and Laboratory of Medical Investigation in Infectious Diseases Pathology (LIM 50) of the University of São Paulo Medical School, São Paulo, SP, Brazil.

\section{REFERENCES}

1. AMATO, J.G.P.; AMATO, V.S. \& AMATO NETO, V. - Aplicação do método de coloração tricrômica em fezes diarréicas de infectados pelo HIV, para pesquisa de microsporídios. Rev. Soc. bras. Med. trop., 32: 277-283, 1999.

2. BRASIL, P.; DE LIMA, D.B.; DE PAIVA, D.D. et al. - Emerging and opportunistic intestinal parasites in HIV-infected patients with chronic diarrhea in Rio de Janeiro, Brazil. J. eukariot. Microbiol., 46: 40S-41S, 1999.

3. BRASIL, P.; DE PAIVA, D.D.; DE LIMA, D.B. et al. - A 3-year follow-up of a Brazilian AIDS patient with protracted diarrhea caused by Enterocytozoon bieneusi. Rev. Inst. Med. trop. S. Paulo, 40: 215-218, 1998.

4. BRASIL, P.; LIMA, D.B.; PAIVA, D.D. et al. - Clinical and diagnostic aspects of intestinal microsporidiosis in HIV-infected patients with chronic diarrhea in Rio de Janeiro, Brazil. Rev. Inst. Med. trop. S. Paulo, 42: 299-304, 2000.

5. BRASIL, P.; SODRÉ, F.C.; CUZZI-MAYA, T. et al. - Intestinal microsporidiosis in HIVpositive patients with chronic unexplained diarrhea in Rio de Janeiro, Brazil: diagnosis, clinical presentation and follow-up. Rev. Inst. Med. trop. S. Paulo, 38: 97-102, 1996.

6. DIDIER, E.S.; ORENSTEIN, J.M.; ALDRAS, A. et al. - Comparison of three staining methods for detecting microsporidia in fluids. J. clin. Microbiol., 33: 3138-3145, 1995.

7. FRANZEN, C. \& MÜLLER, A. - Microsporidiosis: human diseases and diagnosis. Microbes Infect., 3: 389-400, 2001.

8. GARCIA, L.S. - Laboratory identification of the microsporidia. J. clin. Microbiol., 40: 1892-1901, 2002

9. MATHIS, A.; WEBER, R. \& DEPLAZES, P. - Zoonotic potential of the microsporidia. Clin. Microbiol. Rev., 18: 423-445, 2005.

10. MOURA, H.; DA SILVA, J.L.N.; SODRÉ, F.C. et al. - Gram-chromotrope: a new technique that enhances detection of microsporidial spores in clinical samples. J. eukaryot. Microbiol., 43: 94S-95S, 1996.

11. WUHIB, T.; SILVA, T.M.; NEWMAN, R.D. et al. - Cryptosporidial and microsporidial infections in human immunodeficiency virus-infected patients in northeastern Brazil. J. infect. Dis., 170: 494-497, 1994.

Received: 16 March 2006

Accepted: 12 July 2006 